\title{
Review of Fundamentals in selecting Input and Output Variables for Composting Process Automatic Controllers
}

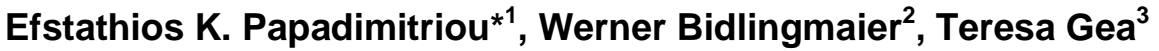

1. Helector-Germany GmbH Global, Solms-Niederbiel, Germany

2. Bauhaus-Universität Weimar, Waste Management Chair, Weimar, Germany

3. Department of Chemical Engineering, ETSE, Universitat Autònoma de Barcelona, Cerdanyola del Vallès, Barcelona, Spain

* Corresponding Author: Efstathios K. Papadimitriou

Helector-Germany GmbH, Riemann Strasse 3, 35606 Solms-Niederbiel, Germany

Tel: +496442207105

fax: $\quad+496442207233$

e-mail: e.papadimitriou@helector-germany.de

This is a pre-print of an article published by Taylor \& Francis in Compost science and utilization on 2010.

Available online: http://www.tandfonline.com/doi/abs/10.1080/1065657X.2010.10736929 Article DOI 10.1080/1065657X.2010.10736929 


\section{Abstract}

This paper provides a critical analysis of the fundamental principles involved in the selection of input and output variables for automatic controllers of composting processes. Research results and technological advancements make available a number of parameters which may be used by a composting process controller. Parameters based on ventilation have been identified as the most appropriate controller output variables. On-line monitoring of odour generation potential and pathogen destruction has not become practically feasible, although recent advances indicate potential for electronic noses and biosensors. On-line measurement of reaction rate heavily depends on the suitability of microbial respirometric methods. Water content of the material being composted may be useful in on-line evaluation of reaction rate if relationships between water loss rate and respiration rate are adequately described. Developments in artificial intelligence offer, however, new avenues regarding real-time estimation of reaction rates. In general, the first experiences from application of artificial intelligence on composting process control indicate potential for substantial utility.

Keywords: composting, process control, control systems, automatic control, input parameters, output parameters, review 


\section{Introduction}

A control system consists of a range of software and hardware components such as sensors, controllers, and transmitters, which are used to perform monitoring, decision making, and control actions on a particular process. In developing an appropriate control system for a composting process, a series of issues has to be considered related to the following topics (Ogunnaike and Ray, 1994):

i. the control objectives;

ii. the selection of input and output parameters of the controller and identification of significant disturbances which may be measured;

iii. the selection of the structure of the control system; and

iv. the design of the controller.

The function of a control system is based on controller input variables, which are used to assign values to controller output variables (Figure 1). The input variables can be controlled parameters of the process and main disturbances affecting the process. Controller input parameters are monitored to judge the past, current or future states of the process. The output variables of a controller are parameters of the process which can be manipulated and refer to control actions. The controlled parameters of a process are mainly chemical and physical attributes, which have to be maintained within certain limits. The parameters that can be manipulated express quantitative and qualitative changes in the control actions (Ogunnaike and Ray, 1994; Yager and Filev, 1994). A disturbance is a process input variable which cannot be manipulated.

A number of control system structures of different level of complexity have been established. The most typical ones are the feedback and feedforward structures. In the case of the former, the controller input variables relate to process outputs while in the case of the latter to disturbances. When a process output of interest cannot be 
measured directly, it might be possible to infer it based on secondary variables. This structure type is termed inferential. Other advanced control structures would include cascade or adaptive control, among others. However, these more complex structures are not commonly used in composting processes.

The design of a controller addresses issues pertinent to developing a control law by which controlled parameters (i.e., process output variables) can be adjusted based on information about the process. In developing a control law, a quantitative description of the process dynamics, i.e., the relationship between process input and output variables, is required.

The key component of a control system, even when a low degree of automation is involved, is the controller. In as much as a controller's input and output variables are critical in deciding on both the controller's design and the structure of a control system, the selection of such parameters is of utmost importance in composting process control.

This report provides a critical review of the fundamental aspects pertinent to selecting controller input and output variables related to automatic control of the composting processes. Hence, the information presented relates to composting systems that are conducive to automatic control and not systems like windrows, which are not. The controller variables are the focus of this paper and not the control algorithms that may be using such variables, or the values that such variables may be assigned in a control algorithm.

\section{Objectives of a composting process control system}

\section{Processing targets}

Composting may be used for purposes ranging from producing highly specific plantgrowing media (e.g., mushroom compost) to bioremediating contaminated land and 
sediments. Different processing targets introduce different requirements of process management which in turn lead to variable control system objectives. In this report, composting is examined in the context of treating organic materials to produce agricultural/horticultural media, or to produce mushroom-growing substrates, or to reduce the organic load of an organic waste prior to its final disposal. These cases represent the vast majority of current composting applications. In addition, systems serving these purposes can be readily comparable with regard to their control objectives due to the similarities of their processing targets, which can be listed as follows:

i. to produce a material of a certain biological stability;

ii. to reduce to appropriate levels, human, animal and plant pathogenic agents in the processed material;

iii. to reduce the potential for odour production during processing; and

iv. to be cost-effective.

Identification of control objectives

The aforementioned processing targets are primarily pursued during the active phase of a composting process, and particularly during the quasi-steady state part of this phase (i.e., the part in which the temperature is kept around a set point, Marrug et al., 1993).

In achieving the processing targets, a control system assists in establishing certain physical and chemical conditions in the composting ecosystem to appropriately drive the pathways and kinetics of the biochemical and chemical reactions. In this context, the following are assumed: the biochemical reactions could be said to account for the entire range of the processing effects during composting (Finstein and Morris, 1975; Miller, 1993); the metabolic pathways sought are aerobic ones; and thermal extinction and microbial antagonism are the mechanisms governing the rate and extent of pathogen reduction. At an operational level, cost-effectiveness is a function of the retention time, 
and energy and land requirements, which are closely related to the operations involved. Overall, the rate of metabolic reactions has been recognised as the single, overriding factor in achieving the processing targets required (Finstein et al., 1986a; Haug, 1996; Kuter et al., 1985; Miller, 1991; Sole-Mauri et al., 2007).

Based on these considerations, the control objectives may be listed as follows:

a) to apply to the active phase of the process;

b) to promote conditions concomitant with aerobic metabolism;

c) to maximise the rate of aerobic reaction;

d) to achieve adequate levels of deactivation of pathogenic agents;

e) to promote homogeneity, i.e., prevent/reduce gradients of the physical/chemical attributes of the ecosystem of the material processed (i.e., the composting ecosystem);

f) to determine retention time, i.e., be able to track down promptly the end of the active phase; and

g) to appropriately synchronise control tasks to optimally satisfy the sum of the control objectives.

The objectives of a controller can be set down in much greater detail provided that the specific processing targets and design characteristics of a composting process are known. However, for the purposes of this report the broad controller objectives listed in the previous paragraph are considered.

\section{Selection of controller input variables}

\section{General}

Considering the control objectives listed above, a composting process should be monitored and evaluated with regard to its degree of aerobiosis, reaction rate, odour 
potential, pathogen destruction, degree of homogeneity, and retention time. For these purposes, potential controlled parameters are shown in Table 1.

An actual controlled parameter is monitored by using one or more of its index parameters (Table 1). For the purpose of feedback or inferential control, a control system should read the value of an index parameter, compare it to a set point value, and subsequently decide whether or not a corrective action should be taken. The influencing parameters (Table 1) are the objects of a corrective action, and as such the control system should be able to judge which of them and to which degree have to be adjusted by means of the manipulation of the controller output parameters. Therefore, the input parameters of a controller should involve both the index and the influencing parameters.

\section{Degree of aerobiosis}

\section{Indices for the degree of aerobiosis}

The term degree of aerobiosis is used here to mean the aerobic share of the overall metabolism occurred during a given course of a composting process. Although theoretically microbes can use oxygen that is contained in the organic matter they biodegrade as well as gaseous oxygen present in the composting matrix, research data about the relative contribution of organic matter oxygen in microbial respiration do not seem to be available. Moreover, as opposed to monitoring gaseous oxygen for automatic control purposes, monitoring of oxygen contained in the material does not appear to be an option. Hence, the role of the organic matter oxygen is not examined further in this paper.

So far, macropore $\mathrm{O}_{2}$ concentration $(\% \mathrm{v} / \mathrm{v})$, measured either directly in the macropores, or in the off-gas, has been widely used as an indicator of oxygen sufficiency and therefore degree of aerobiosis. This may be true only insofar as $\mathrm{O}_{2}$ macropore concentration influences the diffusion driving force, i.e., the $\mathrm{O}_{2}$ concentration 
difference between the biofilm and the macropore environments. However, other factors, such as biofilm thickness, particle size, temperature, and reaction rate, are of equal if not of greater importance in determining the degree of aerobiosis. Indeed, as indicated by Miller (1992), optimum macropore $\mathrm{O}_{2}$ concentrations have been found to range between 5 and $20(\% \mathrm{v} / \mathrm{v})$. Consequently, this indicator is of a rather limited specificity and sensitivity. The microbial respiratory quotient (the ratio of moles of $\mathrm{CO}_{2}$ produced to $\mathrm{O}_{2}$ consumed in a given time span) may be a more appropriate indicator of the degree of aerobiosis since it can differentiate between aerobic and anaerobic/hypoxic conditions independent of the factors at play (Diering, 1979; Moore, 1958; Richard, 1997). Further, Richard (1997) has been able to quantitatively evaluate the parts of aerobic and anaerobic metabolism during composting by using the respiratory quotient $(R Q)$. Nevertheless, currently there is limited information on the impact on the $R Q$ of major composting ecosystem parameters such as feedstock composition, temperature, and water availability. Weppen (2001) showed that the $R Q$ strongly depends on the oxidation state of the substrate involved. Klauss and Papadimitriou, (2001) investigated the utility of exhaust gas $\mathrm{O}_{2}$ concentration, the microbial respiratory quotient, and oxygen consumption rate in evaluating the degree of aerobiosis. The outcomes of that study indicated that any of the aforementioned parameters would not, in isolation, be sufficient for evaluating the degree of aerobiosis of a composting matrix. Comparatively speaking, the oxygen consumption rate was found to have the highest preciseness for this purpose. The evaluation of reaction rate by means of on-line monitoring of the microbial oxygen uptake rate is spreading and a number of works are published reporting oxygen uptake profiles in container-based systems at laboratory scale for process comparison and optimisation ( $\mathrm{Li}$ et al., 2008; Saludes et al, 2007). 
Table 1 shows parameters which influence the degree of aerobiosis and which are potentially able to be controlled during composting. The main factors affecting the degree of aerobiosis are interstitial $\mathrm{O}_{2}$ concentration, porosity of the composting material and temperature. Porosity has been proved to significantly influence the oxygen availability and measurement of its uptake by microbes (Berthe et al., 2007). Porosity is determined by the particle size, the structure of the particle and water availability (Agnew and Leonard, 2003; Richard et al., 2004). Different authors suggest different values for minimum porosity requirements which have been found to vary according to moisture content and mixtures ratios of the organic matrix (Malinska and Richard, 2006). Porosity can be controlled by means of a suitable mixture definition and the proper system design to avoid compression. Mixing of the composting material has shown significant effect on porosity and air permeability (Alburquerque et al., 2006; Szanto et al., 2007) for different types of materials and mixtures which directly influence the airflow patterns through the pile. Finally, temperature affects both the rate of reaction and the gas diffusion rates.

\section{Measurement of indices of aerobiosis}

On the practical side, both macropore $\mathrm{O}_{2}$ concentration and RQ can be measured insitu, in the void space, or in the exhaust gas by making use of available sensor technology. For example, VanderGheynst et al. (1997) successfully developed and tested a sensor capable of measuring $\mathrm{O}_{2}$ concentration $(\% \mathrm{v} / \mathrm{v})$ both in the void space of the material composted and in the exhaust gas. Similarly, Durand and Chereau (1988) used a galvanic oxygen probe to monitor the partial macropore oxygen pressure in a sugar beat solid-state cultivation process. However, in cases which involve the sampling of interstitial gas to be passed through $\mathrm{O}_{2}$ and/or $\mathrm{CO}_{2}$ analysers, the measurement may be troublesome due to sampling difficulties related to moving an adequate volume of gas to the analysers, and the presence of condensate in the gas sampling line (Leton and 
Stentiford, 1990). Concerning the measurement of RQ, this can be calculated based on a volumetric expression of the inlet/outlet concentrations of oxygen and carbon dioxide of the gas provided that constant temperature and pressure levels are applicable at that particular time. It should also be noted that $R Q$ can be worked out only for containerbased composting reactors which include forced ventilation since a known volume of gas has to be monitored. It is, therefore, apparent that for the $R Q$ calculation, assuming a known $\mathrm{O}_{2}$ and $\mathrm{CO}_{2}$ composition of the inlet gas, off-gas analysis also is required. In sewage sludge composting, measurement of the $R Q$ may be compromised by the presence of lime which reacts with $\mathrm{CO}_{2}$ and thus can reduce the $R Q$ value measured. Also, the $\mathrm{CO}_{2}$ liquid-gas equilibrium is $\mathrm{pH}$ dependent, and hence $\mathrm{pH}$ may interfere with assessment of $R Q$. Lastly, it should be remembered that in systems featuring oncethrough ventilation, the off-gas composition represents an average value, as a result of the $\mathrm{O}_{2}$ and $\mathrm{CO}_{2}$ gradients throughout the material composted.

\section{Reaction rate}

\section{Indices of reaction rate}

Generally, on-line, real-time monitoring of the reaction rate at an industrial-scale composting process represents a substantial challenge. This is chiefly due to the lack of a means of directly measuring reaction rate by, for example, measuring microbial cell number, organic matter biodegradation rate, or rate of microbial heat production. Microbial heat output rate can be measured in-situ in container-based systems (Ahn et al., 2007; Harper et al., 1992), but this activity is technically too intensive. A very limited number of studies have been published on measuring reaction rates in the field. Finstein et al. (1986b) worked on sewage sludge composting by using a forced-aerated static pile method. They concluded that the demand for ventilation (fan on-time/unit time), drying tendency (water mass lost/unit time, or moisture content reduction/unit 
time) and $\mathrm{CO}_{2}$ production or $\mathrm{O}_{2}$ consumption rate (mass of gas/unit time) were the most reliable means of monitoring the rate of reaction. Conversely, volatile solids (VS) content was found to be a less sensitive and specific means. Papadimitriou and Balis (1996, 1997) performed a comparative study of a number of potential reaction rate monitoring parameters by employing a container system featuring temperature control by forced ventilation. They found that $\mathrm{O}_{2}$ consumption rate, VS content reduction rate, and moisture content decrease rate were the process parameters best correlated to each other.

$\mathrm{O}_{2}$ consumption rate, contrary to $\mathrm{CO}_{2}$ production rate, has been found to be linearly proportional to the microbial heat output regardless of the substrate and the microbial population involved (Barrena et al., 2006, Cooney et al., 1968, Harper et al., 1992, Messenger et al., 1993). Therefore, it may be used to indicate reaction rate in composting. Weppen (2001) showed close relations among respiratory activity and heat production and demonstrated a good correlation between indirect calorimetry from oxygen consumption and direct calorimetry at laboratory scale. Indirect calorimetry was applied to large scale installations working with bioreactors and was suggested as a method for improving process monitoring.

$\mathrm{CO}_{2}$ production rate has often been used as an indicator of reaction rate as well. Despite the fact that $\mathrm{O}_{2}$ consumption rate is a better indicator of the aerobic metabolic rate than $\mathrm{CO}_{2}$ production rate, the latter indicates the additive biological reaction rate as result of both the aerobic and the anaerobic metabolism. Some studies have indicated that at a particle-micropore level, anaerobic metabolism may play a significant role (Atkinson et al., 1996). Therefore, $\mathrm{CO}_{2}$ production rate may be a more realistic indicator of reaction rate than the rate of consumption of $\mathrm{O}_{2}$, though, as mentioned above, $\mathrm{CO}_{2}$ emissions are $\mathrm{pH}$ dependent. 
Certainly, the respiration rate, assuming that the rest of the factors are constant, depends on the type of substrate biodegraded (Ahn et al., 2007b; Ruggieri et al., 2007). Therefore, pilot scale tests preceding the design of a composting plant would provide optimum respiratory values to be used by a control system. It is important to keep in mind, however, that respiration rates may represent an average value of the respiration rates occurring at different parts of a composting material, depending on the intensity of chemical/physical gradients in such a material.

Water loss is the outcome of the processes of evaporative heat removal driven by microbial heat generation and the movement of interstitial gas. However, in the field, water loss measured as mass of water per unit time is difficult to monitor, unless a container-based system is used which is fitted with equipment to monitor the relative humidity and the temperature of the exhaust gas. Otherwise, the moisture content reduction rate may be used as a substitute, despite it being less sensitive than water loss (Finstein et al., 1986b). Water loss, similar to respiration, may represent an average value of the various losses at different locations of the composting material.

The influencing parameters in a composting ecosystem, which may affect reaction rate, are numerous; for example, Hansen et al. (1989) studied the effect on reaction rate of twenty of them. However, those amenable to on-line monitoring and regulation may be restricted to temperature, degree of aerobiosis, and water availability in the material composted. Coincidentally, these three parameters happen to be the ones which most influence the reaction rate. Further, it is widely accepted that changes in temperature have a much more profound effect on reaction rate than water availability and degree of aerobiosis (Bach et al., 1984; Miller 1992). Water availability has to date been expressed as moisture content. However, the utility of moisture content has largely been questioned as a determinant of microbial activity (Miller, 1989; Prior et al., 1992). In microbiology and in solid-state bioprocessing, water activity has instead been used 
(Nigam and Singh, 1994; Prior et al., 1992). Water activity is defined as the ratio of the vapour pressure of the water in the substrate to the vapour pressure of pure water at the same temperature, (Prior et al., 1992). Miller (1989) questioned the specificity and sensitivity of water activity in moist matrix systems such as composting material. Instead, he suggested that water potential, and specifically matric water potential, is a better indicator. Nevertheless, for a given feedstock, moisture may still be used as a determinant of water availability provided that relations between moisture content and water activity/matric water potential are developed (Miller, 1989).

In composting, real time assessment of reaction rate has been very difficult considering that a multitude of factors impact on it in a non-linear fashion bringing about secondary or higher level impacts, and that these factors vary spatially (gradients in composting material) and temporary (changes during the course of composting). Further, knowledge available from experts and/or operators of composting processes has often an empirical, qualitative character that is not compatible with coding by using deterministic methods. These conditions limit modelling capability for prediction and control purposes, when differential mathematics is used. However, in the last years, artificial intelligence has been applied successfully to modelling, identification, control and optimization of biological processes which manifest similar difficulties as the ones for composting, as far as real-time assessment and control of reaction rate is concerned. Examples include applications to solid state fermentation, anaerobic digestion, biofiltration and bioremediation of contaminated soils (De la Torre-Sánchez, 2005; Elías et al., 2006; Steyer et al., 1997; Valencia, 2002). Their application to composting is currently not well-developed. Bolf et al. (2007) used neural networks to estimate the biodegradation rate from past and current values of compost temperature volatile solids. They stated that neural models are a faster and more reliable option for the continuous monitoring of solid waste composting process in comparison with empirical kinetic 
models. Scholwin (2005) made use of literature and experimental data to develop a fuzzy control system, including a fuzzy, predictive model of the composting process, and a fuzzy inference mechanism for carrying out control actions. One of the features of the predictive model was the estimation of current and future biodegradation rates based on a database containing 4,750 values for the composting process state. The model outputs were in very good agreement with data from laboratory composting reactors. This fuzzy control system is currently undergoing commercialisation (Kompass, 2007).

\section{Measurement of reaction rate indices}

Temperature can be easily monitored either in the composting material or in the exhaust gas. The only aspect of concern with temperature monitoring is the position of measurement (Ekinci et al., 2004). Usually, temperature is measured in the material composted so that a representative picture of the temperature distribution can be obtained. In systems featuring forced-air, once-through ventilation, temperature monitoring should be carried out at frequent intervals along the air path both in the centre and in the periphery of the material. The central readings would be primarily used to check maximum temperature levels while the peripheral ones to monitor air transport efficiency. Temperature throughout the material is also monitored for pathogen destruction purposes. The intervals have to be defined depending on the case, and chiefly depend on the feedstock, height of the material, and ventilation mode. In systems resulting in broad temperature gradients, an indication of the average temperature of the mass has been obtained by working out the median value of the readings taken (MacGregor et al., 1981), and also by a spline interpolation method (Kuter et al., 1985). In general, indirect assessment of composting material temperature by measuring the temperature of the off-gas would not be recommended owing to possible, large and irregular differences between the temperatures of these two media, 
and the slow response of the off-gas temperature compared to the temperature of the material (Fernandez et al., 1995). However, commercial composting systems often rely on monitoring and control actions based on off-gas temperatures, when an adequate amount and quality of data is available regarding empirical relationships between composting material temperature and off-gas temperature.

The measurement of water loss through the exhaust gas can be done by employing a relative humidity sensor and a temperature sensor -e.g., similar to the one used by VanderGheynst et al. (1997). Water loss may also be estimated by using on-line readings of oxygen-based respiration rate. This is due to the relation between water loss and biological heat generation, and therefore oxygen consumption, commonly encountered in aerobic, solid-state bioprocesses of which the main heat removal route is the latent heat or vaporisation (Finstein et al., 1986a; Lonsane et al., 1992; Mitchell et al., 1992; Prior et al., 1992). For example, Sato et al. (1982) worked out a proportionality constant between the total oxygen consumed and water evaporated during the aerobic solid-state fermentation of rice and wheat bran. On the other hand, in-situ, real-time measurement of moisture content in the material composted has turned out to be a more challenging issue. Balascio and Lomax (1989) tested a range of moisture sensors to conclude that tensiometers, gypsum blocks, an electronic hygrometer, and a conductance probe, were inappropriate. A capacitance sensor tested has, however, been found to be of potential use. Stentiford and Zane (1995) concluded that gypsum blocks and glass fibre cells are not suitable for moisture measurement in material composted; conversely electrode probes were found to perform satisfactorily. VanderGheynst et al. (1997) and Imkenberg et al. (1999) developed moisture sensors, which can be used to measure moisture content on-line in the material composted. Fratticcioli et al. (2004) developed a planar resonant sensor for monitoring moisture content in composting systems but moisture measurements were density dependent. In 
container-based systems fitted with a weight loss measurement system, an overallmass-representative moisture content can be worked out by measuring the water carried out by the exhaust gas and the weight loss. Water matric potential has been successfully measured on-line by using a cup tensiometer (Miller, 1989). Water activity has frequently been calculated on-line based on measuring macropore relative humidity assumed to be in equilibrium with the water phase of the solid particles (Gervais, 1989; Prior et al., 1992).

\section{Odour potential}

Odour potential may be defined as the strength of odour expected to arise in the vicinity of a composting plant owing to the concentration of certain volatile compounds in the exhaust gas of a material being composted.

The authors are not aware of any fully proven methods which are capable of measuring odour potential on-line. One may claim that the degree of aerobiosis may be a useful indicator in this context, insofar as aerobic metabolism appears to be the most important, operating, odour-preventing parameter (Miller, 1993). However, it should be noted that the most anaerobic/hypoxic conditions might not be the worst for odour production (Miller, 1991). Some studies have focused on the characterization of odorous emissions during composting by means of the electronic nose technology (Figueiredo and Stentiford, 2001; Rajamaki et al. 2005; Romain et al. 2005). Although this technique is still under development and presents limitations especially when applied to complex and heterogeneous emissions like the produced in waste treatments plants (Baby et al., 2005), it has been successfully applied in the identification of the major odour source of a composting facility (Sironi et al., 2007).

A potentially more appropriate index might involve the measurement of the rate of production of ammonia, volatile fatty acids, and sulphur-based compounds, which are 
the most important classes of compounds, related to odour generation (Defoer et al., 2002; Mao et al., 2006; Miller, 1993).

In view of the lack of a confirmed indicator of odour potential, the monitoring of odour has to solely be based on the influencing parameters (Table 1). Apart from the anaerobic metabolism, reaction rate and temperature are also parameters which influence odour potential in a multitude of ways, including non-biological sulphur reduction, volatilisation of ammonia, and also the potential of assimilation of volatile intermediates by regulating microbial population diversity (Finstein et al., 1986a; Miller, 1993; Pagans et al., 2006).

Practical aspects concerning the monitoring of the degree of aerobiosis and the temperature have already been discussed previously.

\section{Pathogen destruction}

Similar to the odour potential, it seems like a technique to monitor the rate and extent of pathogen destruction on-line has not been developed. Perhaps, biosensors will, in the near future, allow us to follow the destruction rate and extent of indicator-pathogens (Hobson et al, 1996; Lazcka et al, 2007).

In the meantime, the rate and extent of pathogen destruction can be determined by monitoring the temperature/time profile in the material, and the rate of reaction. The available knowledge of temperature-exposure issues is sufficient to achieve the desirable destruction levels of common pathogens (Epstein, 1997; Wichuk and McCartney, 2007). Apart for influencing thermal deactivation of pathogens, temperature is also a factor affecting non-thermal mechanisms for pathogen reduction such as antagonism and predation. Non-thermal pathogen reduction can be more important than thermal reduction, depending on the pathogen involved (Papadimitriou et al., 2003; Papadimitriou and Stentiford, 2003). However, lack of practical tools for measuring non 
thermal parameters has essentially left temperature and exposure time as the only real time parameters suitable for automatic control.

Governmental standards in USA, Canada and Europe establish time-temperature criteria to achieve desired pathogen inactivation in composted materials. Martens (2004; 2005) analyzed 2702 time-temperature records of 23 composting plants belonging to different design types, including windrows and in-vessel systems, to study the hygienic performance. The portion of the entire data set which met legal temperature requirements fell below $50 \%$ for about $25 \%$ of the plants, and this was exclusively attributed to processing conditions, particularly temperature. Likewise, Brinton and Blewett (2008) found $55 \%$ and $11 \%$ of a large number of bulk and bagged composts, respectively, failed to satisfy US Environmental Protection Agency limits for pathogens. They also attributed this to temperature gradients in the composting material.

Wichuk and McCartney (2007) undertook a broad review on the effectiveness of current time-temperature regulations on pathogen inactivation during composting. Although several works confirmed sanitisation through the absence of indicator microorganisms in final compost, many others found pathogens in compost produced in systems, which apparently met the time-temperature requirements. Some explanations given for pathogen presence after compost being exposed to high temperatures are recontamination from external sources or regrowth from undetectable levels, the latest applicable only to bacteria but not to viruses, protozoa or helminthes. It must be taken into account that presence of pathogen or indicator microorganisms are often assessed by culture-based methods. New methodologies such as PCR have resulted in pathogen values up to 5 orders of magnitudes higher than culture methods for $E$. coli and Salmonella spp. (Wèry et al. 2008). However PCR stills presents a very high detection limit to be used with confidence in solid materials. 
In any case, the most commonly cited explanation for pathogen survival during composting is the existence of temperature gradients in the material (Wichuk and McCartney, 2007). Authors emphasized that time-temperature regulations should not be understood as average values but they apply to all the composting mass. Exposing all the material to the required temperature conditions is essential since pathogens could survive in low temperature pockets and eventually colonise other parts of the material. Papadimitriou and Stentiford $(2003 ; 2004)$ demonstrated that even a part of the material mass as small as $0.01 \%$ is not subject to pathogen reduction may have a detrimental effect on the net pathogen reduction of the entire material. The inherent difficulty in achieving a homogeneous temperature profile in a large composting mass is well known and covered exhaustively in the following sections of 'Degree of homogeneity' and 'Control of temperature gradients'.

\section{Degree of homogeneity}

Gradients occur in composting both at the particle and at the matrix levels. This section is concerned with the latter, the former being rather difficult to manipulate.

The homogeneity of a composting matrix can be assessed based on the gradients of temperature, moisture, macropore oxygen concentrations, and porosity. The first three of these are particularly important along the gas pathway induced by forced ventilation (Ekinci et al., 2006), and can be measured as discussed previously. The porosity gradient is relevant along the direction of gravity, and is measured by using pressure drop in forced air along this direction (Ahn et al., 2008; Fernandez et al., 1995; Durand and Chereau 1988; Richard et al., 2004).

The factors influencing the homogeneity of a composting matrix depend on the parameter involved (Table 1). The compressive pressure owing to gravity is mainly responsible for porosity gradients while moisture is of a secondary importance in this 
sense (Das and Keener, 1996; Higgins 1982). Compressive stress can affect temperature and oxygen gradients as a result of its impact on the movement of interstitial gas (Ahn et al., 2008). The temperature differential between the interstitial gas and the solid particles, and the mode of interstitial gas movement appear to be the main controlled parameters responsible for temperature and moisture gradients. Macropore $\mathrm{O}_{2}$ gradients are induced primarily owing to the combined effects of gravitational forces, the mode of gas movement, and the velocity of the interstitial gas.

Pressure drop across a composting mass can easily be measured by using various instruments (Harper et al., 1992; Durand and Chereau 1988; Fernandez et al., 1995). The mode of interstitial gas movement depends on the pattern of forced ventilation, i.e., whether the latter occurs in a positive and/or negative pressure mode, and on a continuous or intermittent basis.

\section{Retention time}

The time the material processed has to undergo active composting can be judged based on the material temperature trend, the respiration rate and the cumulative loss of organic carbon (De Guardia et al., 2008; Saludes et al., 2007; Sellami et al., 2008). The latter demands knowledge of the readily biodegradable concentration of carbon present in the feedstock. Although there is not a consensus within the research community about a reliable measure for biodegradable matter content in organic solid wastes, cumulative $\mathrm{CO}_{2}$ production during the composting process has been suggested as an indicator of biodegradable organic carbon (Komilis, 2006; Sánchez, 2007). On the other hand, Tremier et al. (2005) and De Guardia et al. (2008) have used the rate of microbial oxygen uptake to identify the transition of the composting process into the phase which involves less biodegradable carbon. 
The use of $R Q$ in judging retention time has not, thus far, been studied with relation to composting. The potential of this indicator is based on the consideration that following a substantial reduction of the readily biodegradable compounds, microbial cell lysis may commence which may lead to a noticeable increase of the RQ (Govind et al., 1997). An estimate of the retention time expected under certain operating conditions can be obtained by carrying out pilot scale trials. Reaction rate is the single factor influencing the retention time.

The practical aspects of monitoring the parameters involved in the control of retention time have already been discussed in this report in the sub-sections dealing with degree of aerobiosis and reaction rate. It should be added, however, that the loss of carbon and the rate of microbial oxygen uptake can be measured on-line by monitoring $\mathrm{CO}_{2}$ release and $\mathrm{O}_{2}$ consumption, both of which are however geared towards container-based systems.

\section{Selection of controller output variables}

\section{General}

Manipulated parameters possibly suitable for use in a composting automatic control system are primarily associated with ventilation, water addition, and material mixing (Table 2). These are discussed with reference to the process parameters intended to be controlled. It should also be noted that the term inlet gas is used here to mean fresh air, or a mixture of fresh air with recirculated off-gas forced into the material being composted.

Control of temperature 
The most significant manipulated parameters which can be used in controlling temperature are flow rate and temperature of the inlet gas, the pressure and actuation pattern of ventilation, the duration of a ventilation event, the material mixing frequency, and the rate of water addition. The latter is just a side effect of the correction of water content and is not usually employed for temperature regulation purposes.

Temperature control can be carried out by removing heat by means of forced ventilation. In solid-state, energy dense bioprocessing systems, $80-90 \%$ of the heat generated is removed by evaporative cooling (i.e., the latent heat of vaporisation). The remaining $10-20 \%$ is removed due to the heat conduction of dry gas (i.e., the sensible heat) (Finstein et al., 1986a, Harper et al., 1992, Lonsane et al., 1992; Sato et al., 1982). The flow rate and temperature of the inlet gas determine the heat removal rate. The latter should be varied depending on the heat production rates. Heat removal is usually controlled by manipulating the inlet gas flow rate. Adjustment of the temperature of the inlet gas is practised in systems featuring off-gas cooling and recirculation. In removing heat, the pressure patterns of ventilation may be said to be the ones of positive pressure, negative pressure, alternate positive-negative pressure, and a combination thereof resulting from applying off-gas recirculation. Aeration through positive pressure is considered to be preferable to negative pressure due to reasons related to gas movement efficiency, uniformity of heat distribution, enhancement of matrix porosity, and energy consumption (Goyal 1983; Miller et al., 1982). With regard to the actuation pattern, ventilation may take place either intermittently, or continuously. Both of these patterns can remove heat effectively. Intermittent ventilation for heat removal purposes can be performed with reference to a temperature set point. Continuous ventilation would, in addition, have to be directly related to on-line microbial heat production indicators to make it possible to appropriately vary the gas flow rate to either avoid foreseeable temperature disturbances or correct a disturbance which has occurred. In 
the intermittent mode, the duration of a ventilation event depends on the amount of heat stored in the compost matrix and the heat loss rates, and it can be defined based on the upper and lower permissible temperature levels.

Two main generic strategies for the actuation of ventilation may be distinguished relevant to controlling the temperature level. One aims at promoting heat generation by switching on the ventilation system once the temperature reaches a set level (Finstein et al., 1980). The other aims at suppressing heat generation by ceasing the ventilation once temperature reaches a given level (Schulze, 1962). The latter, despite bringing about an excellent temperature control, led to apparent oxygen starvation at least across half of the mass of the material composted. In addition, this approach contradicts the notion of maximising reaction rate. So far, there has been no attempt made to study this system under a management protocol, which would alleviate oxygen starvation. The alternative actuation strategy (i.e. that of activating ventilation once temperature has reached a given temperature level) can lead to efficient temperature control without leading to oxygen starvation problems (Finstein et al., 1986a).

Material mixing can only introduce short term temperature changes, and is also a more costly and operation-intensive activity. For example, Laukevics et al. (1984) employed a $1.5 \mathrm{~m}^{3}$-capacity rotating reactor agitated at a rate of $1 \mathrm{~min}$ per $5 \mathrm{~min}$. They concluded that heat removal was poor despite the fact that the reactor was also fitted with a water jacket and an internal heat exchanger.

The regulation of the aforementioned temperature-controlling manipulated parameters could easily be practiced from a practical point of view.

\section{Control of temperature gradients}

The inlet gas flow rate, temperature of the composting material, actuation and pressure pattern and duration of ventilation, and material mixing appear to be the most 
important manipulated parameters in controlling temperature gradients. Material mixing can reduce temperature gradients but it appears to be a rather expensive method for this purpose. It seems to be more sensible to employ manipulated parameters linked to forced ventilation, the latter being an almost indispensable operation of any wellmanaged composting system. Inlet gas temperature would greatly affect the heat removal capacity of the inlet gas, and the temperature gradient as well. However, for cost reasons, control of the temperature of the inlet gas is practised to a limited degree and only at container-based systems featuring off-gas recirculation (Ekinci et al., 2006). Depending on the duration of a ventilation event and the flow rates involved, intermittent aeration events may result in a substantially diminished temperature gradient compared to continuous aeration (Hong et al., 1998). However, available information on this topic is insufficient to enable the development of controller design criteria. The velocity of ventilation affects the temperature distribution by counteracting compressive stress and allowing more uniform heat production and removal. The pressure mode of ventilation affects the direction of the temperature gradient with lower and higher temperatures being registered at the gas inlet and outlet, respectively. Examples of temperature gradients observed in aerobic, solid-state bioprocessing, which employ positive pressure ventilation, are $23^{\circ} \mathrm{C} / \mathrm{m}$ for sewage sludge composting (Finstein et al., 1986a), and $300^{\circ} \mathrm{C} / \mathrm{m}$ for tempeh fermentation (Prior et al. (1992) quoting Rathbum and Shuler (1983)). Alternate positive-pressure ventilation may substantially reduce the temperature gradients in a composted mass (Koenig and Bari, 1999; Sesay et al., 1998). In designing such a system the frequency of switching between positive and negative pressure has to be based on temperature differential and heat removal requirements. For example, Sesay et al. (1998) were not capable of efficiently removing heat due to an excessively frequent switching between positive and negative pressure which resulted in 
a limited replacement of interstitial gas with fresh air. Off-gas recirculation combined with temperature control of the inlet gas can result in temperature gradients, along the inlet gas flow pathway, as small as approximately $2^{\circ} \mathrm{C} / \mathrm{m}$ (Harper et al., 1992).

\section{Control of water availability}

Water availability can be controlled by regulating the inlet gas flow rate and temperature, the duration of aeration events, the reaction rate, the mixing of the material, and the frequency and rate of water addition (Table 2). Of those, the frequency and rate of water addition, the reaction rate, and the temperature and flow rate of the inlet gas are the most influential parameters.

The flow rate and temperature of the inlet gas in conjunction with the reaction rate (i.e., heat generation rate) determine the rate of water loss by means of evaporative cooling. Evaporative cooling can account for up $98 \%$ of the overall amount of water removed (Finstein et al., 1986a), the rest of it being attributed to dry gas convection. Heat removal to maintain the temperature at levels beneficial to microbial activity leads to greater heat production, which, in turn, calls for more ventilation, thus resulting in a greater removal of water. Consequently, heat removal through ventilation and preservation of water availability are contradictory activities. This has indeed been one of the core challenges in composting process control due to the lack of alternative means of effective heat removal (see section on temperature control). Often, in solidstate fermentation studies, it has been claimed that water availability can, to a substantial extent, be controlled by adjusting the humidity of the inlet gas (Bartsow et al., 1988; Fernandez et al., 1995; Gervais and Bazelin, 1986; Narahara et al., 1984; Ryoo et al., 1991). However, such studies have been performed in laboratory reactors featuring a large outer surface to volume ratio. Consequently, contrary to field systems, they allow water conservation due to conduction being the major mechanism of heat removal. 
The humidity of the inlet gas may play a greater role in water preservation only in systems of a relatively low energy density. For instance, Durand and Chereau (1988) used this technique to control the water loss of a solid-state, low-energy density culture which was carried out at $25 \stackrel{\circ}{ } \mathrm{C}$ in 1 -tonne capacity reactor and involved raw sugar beat and a mutant of Viride T.S. Unfortunately, the energy density of a composting matrix is relatively high for such a method to be used successfully.

At an operational level, water addition seems to be the only means of counteracting water loss. The frequency of water addition depends primarily on the structural characteristics of the substrate, the rate of water loss, and the stage of processing (i.e., the remaining amount of energy to be released). Optimal moisture contents to enhance microbial activity have been found close to the water holding capacity for different materials (Ahn et al., 2007b). As a rough rule of thumb, a moisture content of $45 \%$, expressed on a wet weight basis, may be used as a threshold value for triggering a water addition event (US Composting Council, 1994). At this point, it should be interesting to underline that microbial activity may progress without major reductions at moisture contents as low as $30 \%$ (Miller et al., 1983). This has been attributed to the fact that reduced water availability limits the microbes physically by reducing their mobility. However, in a well-colonised material, as a result of an optimum starting water availability, it may be possible to operate at such lower moisture levels without experiencing substantial inhibitive effects (Miller, 1989). During a water addition event, the rate of water addition should be greater than the instantaneous rate of water loss, and should also make sure that the water reaches the desirable levels as soon as possible without causing water clogging. In general, addition of water without being accompanied by material mixing has been problematic, due to water channelling and clogging phenomena. 
Water availability may be best addressed at the stage of feedstock preparation. A feedstock may be appropriately prepared to contain an energy content of which the evaporative loss, due to the amount and type of readily biodegradable compounds present, will not cause excessive depletion of water. In other words, the energy density of the feedstock would be the controlled variable. Alternatively, a water source may be used as part of the feedstock to counteract excessive water losses. For example, Sato et al. (1982) used wetted woody pulp particles (i.e., the centrifugal residue of a paper mill) to maintain appropriate water levels in an aerobic, solid-state bioprocessing featuring evaporative cooling.

Practically speaking, all the manipulated parameters discussed here are feasible and have also been widely applied. The addition of water in container-based systems may be of particular concern owing to the corrosive environment usually found in a reactor, and the costs involved in fitting and operating mixing apparatuses.

\section{Control of water content gradients}

The flow rate, temperature, actuation and pressure pattern, and event duration of ventilation as well as material mixing are the main manipulated parameters in controlling water gradients. In systems employing ventilative heat removal, water availability gradients (i.e., gradients of moisture content in the material) are also closely linked to temperature gradients owing to heat removal through water evaporation. Hence, the achievement of a homogeneous temperature throughout the material composted would also keep water availability gradients to a minimum. The amelioration of a water availability gradient would be best carried out by applying material mixing. For example, Berthe et al. (2007) and Fernandez et al. (1995) successfully controlled moisture gradients by mixing the material based on a heuristic rule. The reduction of alreadyexisting moisture gradients by employing ventilation-based manipulated parameters 
seems a very complicated task so far as water has to be convectively removed from areas of a higher water concentration to be subsequently transported and delivered to areas of a lower water availability. Ventilation may easily, however, force free water to areas of water deprivation where it could be absorbed by the material composted.

\section{Control of $R Q$ and macropore $\mathrm{O}_{2}$ concentration}

During processing, $R Q$ may be influenced by regulating the macropore concentration of oxygen and the reaction rate. The macropore oxygen level is affected by the reaction rate (i.e., oxygen uptake rate) and oxygen delivery rate. Therefore, it would make sense to examine the control of $R Q$ together with that of macropore $\mathrm{O}_{2}$ concentration. Manipulated parameters most relevant to the control of these two parameters are the flow rate and velocity of the inlet gas, the ratio of the amount of fresh air to the amount of recirculated off-gas, the duration of a ventilation event, and the frequency of the material mixing.

In maximising the rate of reaction, the inlet gas has to have an appropriate flow rate and oxygen concentration so that it can maintain the concentration of interstitial oxygen at such levels to accomplish the best-achievable $R Q$ value. Similarly, ventilation velocity can help increase the degree of aerobiosis, and consequently the rate of reaction, by promoting a greater oxygen diffusion into the biofilm. For example, Miller (1996) increased the reaction rate by $25 \%$ by increasing the ventilation velocity, despite the fact that there was no change in the macropore oxygen concentration. On the other hand, if maintenance of aerobiosis is the only target, without considering temperature or other effects on the reaction rate, the reaction rate would be reduced to match the oxygen delivery rates associated with that ventilation rate which is capable of maintaining the lowest possible anaerobic metabolism. The duration of a ventilation event is defined by the delivery of the amount of oxygen required. The ratio of fresh air to recirculated gas 
determines the maximum possible oxygen concentration in the macropores. At composting rates commonly found, material mixing will only allow momentary influence on the interstitial oxygen concentration. Specifically, an interstitial oxygen concentration of about $20 \%(\mathrm{v} / \mathrm{v})$, immediately recorded after aeration had taken place, can decline to less than $10 \%$ within a few minutes (US Composting Council, 1994). For a given oxygen uptake rate, the frequency of mixing depends chiefly on the pore space (Mitchell et al., 1992). Frequent mixing may result in a decreased porosity by virtue of an increased particle friction causing particle size reduction (Szanto et al., 2007), and also lead to greater operating cost, as it would have to operate in tandem with a forced ventilation system required to bring about temperature control (Mitchell et al., 1992). Mixing would not, therefore, be a very efficient means of providing the oxygen necessitated during the active phase of composting.

The monitoring and adjustment of those manipulated parameters for the control of $R Q$ and macropore oxygen concentration is widespread (Haug, 1993, Mitchell et al., 1992).

\section{Control of $\mathrm{O}_{2}$ concentration gradients}

The oxygen concentration of the inlet gas and the flow rate and event duration of ventilation can be said to be the most significant manipulated parameters for controlling macropore oxygen gradients. Control of temperature gradients based on employing ventilation-based manipulated parameters may also guarantee control of gradients of macropore oxygen concentration. This is based on the common observation that forced ventilation can achieve oxygen transfer throughout the gaseous interstices in a shorter time than the one it requires to bring about convective heat transfer to reduce temperature gradients. Material mixing can certainly be employed to effectively control macropore oxygen gradients either alone or in conjunction with ventilation-based parameters. 


\section{Control of respiration rate}

The manipulated parameters applicable to the control of the reaction rate (i.e., respiration rate) have already been dealt with earlier in the subsections on the control of temperature, water availability, and $R Q$ and macropore oxygen concentration.

\section{Control of compressive stress}

Compressive stress may be controlled by adjusting the inlet gas velocity and pressure actuation pattern, and also by mixing the material. A greater velocity combined with continuous ventilation aids in maintaining an open matrix. On the contrary, intermittent aeration may or may not result in increased compaction depending on the ventilation velocity and event duration, and the structural characteristics of the feedstock involved. Contrary to the positive pressure ventilation, negative pressure ventilation certainly increases compressive forces. Continuous off-gas recirculation can substantially contribute to control the porosity of the substrate matrix by counteracting the compressive forces (Maile, 2007).

\section{Disturbance variables}

Some of the main disturbances, which may take place during composting include: thermal diffusivity of the material being composted, rate of gas diffusion into and from the biofilm, particle size and shape, thermal conductivity of the material composted and others. A comprehensive list of the main disturbances is presented in Table 3.

\section{Acknowledgements}


This work was made possible through the project "DBU Vorhaben AZ 08837" which was funded by the German, federal Environmental Foundation. 


\section{References}

Agnew, J.M., Leonard, J.J. 2003. The physical properties of compost. Compost Sci. Util., $11: 238-264$.

Ahn, H.K., Richard, T.L., Choi, H.L. 2007. Mass and thermal balance during composting of a poultry manure - wood shavings mixture at different aeration rates. Process Biochem. 42:215-223.

Ahn, H.K., Richard, T.L., Glanville, T.D. 2007b. Optimum moisture levels for biodegradation of mortality composting envelope materials. Waste Manage., doi:10.1016/j.wasman.2007.05.022. 2007.

Ahn, H.K., Richard, T.L., Glanville, T.D. 2008. Laboratory determination of compost physical parameters for modeling of airflow characteristics. Waste Manage., 28:660670.

Alburquerque, J.A., Gonzálvez, J., García, D., Cegarra, J. 2006. Measuring detoxification and maturity in compost made from "alperujo", the solid by-product of extracting olive oil by the two-phase centrifugation system. Chemosphere., 64:470477.

Atkinson, C.F., Jones, D.D., Gauthier, J.J. 1996. Putative anaerobic activity in aerated composts. J. Ind. Microbiol., 16:182-188.

Baby, R.E., Cabezas, M.D., Labud, V., Marqui, F.J., Walsöe de Reca, N.E. 2005. Evolution of thermophilic period in biosolids composting analyzed with an electronic nose sensor. Sensor. Actuat. B-Chem., 106:44-51.

Bach, P.D., Shoda, M., Kubota, H. 1984. Rate of dewatered sewage sludge in continuously mixed isothermal reactor. J. Ferment. Technol., 62:285-292.

Balascio, C.C., Lomax, K.M., 1989. A comparative study of moisture sensors for use in mushroom beds. T. ASAE., 32:928-933. 
Barrena, R., Cánovas, C., Sánchez, A. 2006. Prediction of temperature and thermal inertia effect in the maturation stage and stockpiling of a large composting mass. Waste Manage., 26:953-959.

Bartsow, L.M., Dale, B.E., Tengerdy, R.P. 1988. Evaporative temperature and moisture control in solid substrate fermentation. Biotechnol. Tech., 2:237-242.

Berthe, L., Druilhe, C., Massiani, C., Tremier, A., de Guardia, A. 2007. Coupling a respirometer and a pycnometer to study the biodegradability of solid organic wastes during composting. Biosyst. Eng., 97:75-88.

Bolf, N., Kopči, N., Briški, F., Gomzi, Z. 2007. Software Sensors for Monitoring of a Solid Waste Composting Process. Chem. Pap., 61:98-102.

Brinton, W.F., Blewett, H.C. 2008. Fecal indicators and pathogenic bacteria in USA market ready green composts and relationship to management parameters. In: Proceedings ORBIT 2008. 13-15 October, Wageningen, The Netherlands. RodicWiersma, L., Barth, J., Bidlingmaier, W., Bertoldi, M., Diaz, L.F., (Eds.).

Cooney, C.L., Wang, D.I.C., Mateles, R.I. 1968. Measuring of heat evolution and correlation with oxygen consumption during microbial growth. Biotechnol. Bioeng., $11: 269-281$.

Das, K., Keener, H.M. 1996. Process control based on dynamic properties in composting: moisture and compaction considerations. In: de Bertoldi, M., Sequi, P., Lemmes, B., Papi, T. (Eds). The Science of Composting, Part 1. Blackie Academic \& Professional, Glasgow, Scotland. pp. 117-125.

De Guardia, A., Petiot, C., Rogeau, D. 2008. Influence of aeration rate and biodegradability fractionation on composting kinetics. Waste Manage., 28:73-84.

De la Torre-Sánchez, R., Baruch, I., Barrera-Cortés, J. 2005. Neural prediction of hydrocarbon degradation profiles developed in a biopile. Expert Syst. Appl., 31:383389. 
Defoer, N., De Bo, I., Van Langenhove, H., Dewulf, J., Van Elst, T. 2002. Gas chromatography-mass spectrometry as a tool for estimating odour concentrations of biofilter effluents at aerobic composting and rendering plants. J. Chromatogr. A., 970:259-273.

Diering, B. 1979. Research in a modified process for the cotreatment of waste and sludge. PhD Thesis. Technische Hochschule Aachen, Aachen, Germany. [In German]

Durand, A., Chereau, D. 1988. A new pilot reactor for solid-state fermentation: application to the protein enrichment of sugar beet pulp. Biotechnol. Bioeng., 31:476486.

Ekinci, K, Keener H.M., Akbolat, D. 2004. Effect of Thermocouple Location on the Optimum Composting Rate. Biosyst. Eng., 89:345-353.

Ekinci, K, Keener H.M., Akbolat, D. 2006. Effects of feedstock, airflow rate, and recirculation ratio on performance of composting systems with air recirculation. Bioresource Technol., 97:922-932.

Elías, A., Ibarra-Berastegi, G., Arias, R., Barona, A. 2006. Neural networks as a tool for control and management of a biological reactor for treating hydrogen sulphide. Bioproc. Biosyst. Eng., 29:129-136.

Epstein, E. The Science of Composting. 1997. Technomic Publishing Company. USA. Fernandez, M., Ananias, J., Solar, I., Perez, R., Chang, L., Agosin, E. 1995. Advances in the development of a control system for a solid substrate pilot bioreactor. In: Proceedings of the $2^{\text {nd }}$ International Symposium on 'Solid Substrate Fermentation' FMS'95, Montpellier, France. pp. 155-168.

Figueiredo, S. A. B., Stentiford, E. I. 2001. In: Proceedings of the International Conference 2001 on "Biological processing of waste: a product-oriented perspective". Spanish Waste Club and ORBIT Association (Eds.). pp. 41-44. 
Finstein, M.S., Morris, L.M. 1975. Microbiology of municipal waste composting. Adv. Appl. Microbiol., 19:113-151.

Finstein, M.S., Cirello, J., MacGregor, S. T., Miller, F. C., Psarianos, K. M. 1980. Sludge Composting and Utilization: rational approach to process control. US EPA Report No. EPA/C-340678011. Environmental Protection Agency, Washington DC, USA.

Finstein, M.L., Miller, F.C., Strom, P.F. 1986a. Waste treatment composting as a controlled system. In: Rhem, H.J., Reed, G. (Eds.) Biotechnology, Vol. 8. VCH Verlagsgesellschaft, Weinheim. pp. 363-398.

Finstein, M.S., Miller, F.C., Strom, P.F. 1986b. Monitoring and evaluating composting process performance. J. Water Pollut. Con. F., 58:272-278.

Fratticcioli, E., Dionigi, M., Valentini, F., Sorrentino, R. 2004. Monitoring moisture content in composting systems using a planar resonant sensor. In: IMTC 2004 Instrumentation and measurement Technology Conference. Como, Italy, 18-20 May. pp. $339-342$.

Gervais, P., Bazelin, C. 1986. Development of a solid-substrate fermentor allowing the control of the substrate water activity. Biotechnol. Lett., 8:191-196.

Gervais, P. 1989. New sensor allowing continuous water activity measurement of submerged or solid-substrate fermentations. Biotechnol. Bioeng., 33:266-271.

Govind, R., Gao, C., Lai, L., Tabak, H.H. 1997. Continuous, automated and simultaneous measurement of oxygen uptake and carbon dioxide evolution in biological systems. Water Environ. Res. 69:73-80.

Goyal, S. 1983. Choosing between induced- and forced-draft fans. Chem. Eng. - New York. February 7:92-93.

Hansen, R.C., Keener, H.M., Hoitink, H.A.J. 1989. Poultry manure composting: an exploratory study. T. ASAE., 32:2151-2158. 
Harper, E., Miller, F.C., MacCauley, B.J. 1992. Physical management and interpretation of an environmentally controlled composting ecosystem. Aust. J. Exp. Agr., 32:657667.

Haug R.T. 1993. The Practical Handbook of Compost Engineering. CRC Press, Lewis Publishers, USA.

Haug, R.T. 1996. Composting plant design and process management. In: The Science of Composting. de Bertoldi M., Sequi P., Lemmes B., and Tapi T. (Eds.), Part 1. Blackie Academic \& Professional. pp. 60-70.

Higgins, A.J. 1982. Ventilation for static pile composting. BioCycle, 23:36-41.

Hobson N.S., Tothill F. and Turner A.P.F. 1996. Microbial Detection. Biosens. and Bioelectr., 11:455-477.

Hong, J.H., Keener, H.M., Elwell, D.L. 1998. Preliminary study of the effect of continuous and intermittent aeration on composting hog manure amended with sawdust. Compost Sci. Util., 6:74-88.

Imkenberg, F., Kickellhein, J., Abou-Zeid, A. 1999. Determination of the relative and absolute humidity in compost piles by differential spectroscopy using tuneable diode lasers. In: Proceedings of ORBIT 1999, Part 1, Research in and Implementation of Process Technology. Bidlingmaier, W., de Bertoldi, M., Diaz, L.F., Papadimitriou, E.K. (Eds.). Rhombos Verlag, Berlin, Germany. pp. 77-83.

Klauss, M., Papadimitriou, E. K. 2001. Monitoring the degree of aerobiosis of a composting matrix. In: Proceedings of ORBIT 2001, Part II, pp. 337-344.

Koenig, A., Bari, Q.H. 1999. Effect of different forced aeration methods on vertical temperature distribution and reaction rates during composting. In: Proceedings of ORBIT 1999, Part 1, Research in and Implementation of Process Technology. Bidlingmaier, W., de Bertoldi, M., Diaz, L.F., Papadimitriou, E.K. (Eds.). Rhombos Verlag, Berlin, Germany. pp. 93-100. 
Komilis, D.P. 2006. A kinetic analysis of solid waste composting at optimal conditions. Waste Manage., 26:82-91.

Kompass. 2007. Success in composting through process control. Product Brochure on Navi Rot@ by KOMPASS GmbH, Viersen, Germany.

Kuter, G.A., Hoitink, H.A.J., Rossman, L.A. 1985. Effects of aeration and temperature on composting of municipal sludge in a full-scale vessel system. J. Water Pollut. Control Federation., 57:309-315.

Laukevics, J.J., Aspite, A.F., Viesturs, U.E. Tengerdy, R.P. 1984. Solid substrate fermentation of wheat straw to fungal protein. Biotechnol. Bioeng., 27:1465-1474.

Lazcka O., Del Campo F.J., Muñoz F.X. 2007. Pathogen detection: A perspective of traditional methods and biosensors. Biosens. And Bioelectr., 22:1205-1217.

Leton, T.G., Stentiford, E.I. 1990. Control of aeration in static pile composting. Waste Manage. Res., 8:299-306.

Li, X., Ruihong, Z., Pang, Y. 2008. Characteristics of dairy manure composting with rice straw. Bioresource Technol., 99:359-367.

Lonsane, B.K., Saucedo-Castaneda, G., Raimbault, M., Roussos, S., ViniegraGonzalez, G., Ghildyal, N.P., Ramakrishna, M., Krishnaiah, M.M. 1992. Scale-up strategies for solid state fermentation systems. Process Biochem., 27:259-273.

MacGregor ,S.T., Miller, F.C., Psarianos, K.M., Finstein, M.S. 1981. Composting process control based on interaction between microbial heat output and temperature. Appl. Environ. Microb., 41:1321-1330.

Maile, A. 2007. Personal Communication. Heilit Umwelttechnik GmbH, Germany.

Malinska, K.A., Richard, T.L. 2006. The impact of physical properties and compaction on biodegradation kinetics during composting. In: Proceedings ORBIT 2006. 13-15 September, Weimar, Germany. Kraft, E., Bidlingmaier, W., Bertoldi, M., Diaz, L.F., Barth, J. (Eds.) 125-132. 
Mao, I-F., Tsai, C-J., Shen, S-H, Lin, T-F, Chen, W-K, Chen, M-L. 2006. Critical components of odors in evaluating the performance of food waste composting plants. Sci. Total Environ., 370:323-329.

Marrug, C., Grebus, M., Hansen, R.C., Keener, H.M., Hoitink, H.A.J. 1993. A kinetic model of the yard composting process. Compost Sci. Util., 1:38-51.

Martens, J. 2005. Indicator methods to evaluate the hygienic performance of industrial scale operating Biowaste Composting Plants. Waste Manage., 25:435-444.

Messenger, J.R., de Villers, H.A., Ekama, G.A. 1993. Evaluation of the dual digestion system, part 2: operation and performance of the pure oxygen aerobic reactor. Water SA., 19:193-200.

Miller, F.C., MacGregor, S.T., Psarianos, K.M., Cirello, J., Finstein, M.S. 1982. Direction of ventilation in composting wastewater sludge. J. Water Pollut. Control Federation., $54: 111-113$

Miller, F.C. MacGregor S.T., Psarianos K.M., Finstein M.S. 1983. A composting process failure: diagnosis and remedy. In: Proceedings of the $15^{\text {th }}$ Mid-Atlantic Industrial Waste Conference. Ann Arbor, USA. pp. 463-471.

Miller, F.C. 1989. Matric water potential as an ecological determinant in compost, a substrate dense system. Microb. Ecol., 18:59-71.

Miller, F.C. 1991. Biodegradation of Solid Wastes by Composting. In: Biodegradation of wastes. Martin A.M. (Ed.), Elsevier Science Publisher Ltd. pp. 1-30.

Miller, F.C. 1992. Composting as a process based on the control of ecologically selective factors. In: Soil Microbial Ecology. Meeting F.B. (Ed.). Markel Dekker, Inc., NY, USA. pp. 515-544.

Miller, F.C. 1993. Minimizing odor generation. In: Science and Engineering of Composting: design, environmental, microbiological, and utilization aspects. Hoitink H.A.J. and Keener H.M. (Eds.). Renaissance Publications, Ohio. pp. 219-241. 
Miller, F.C. 1996. Heat evolution during the composting of sewage sludge. In: The Science of Composting, Part 1. de Bertoldi M., Sequi P., Lemmes B., and Papi T. (Eds). Blackie Academic \& Professional, Glasgow, Scotland. pp. 106-115.

Mitchell, D.A., Lonsane, B.K., Durand, A., Renaud, R., Almanza, S., Maratray, J., Desgranges, C., Crooke, P.S., Hong, K., Tanner, R.D., Malaney, G.W. 1992. General principles of reactor design and operation for SSC. In: Solid Substrate Cultivation. Doelle, H.W., Mitchell, D.A., Rolz, C.W. (Eds.). Elsevier Applied Sciences. pp. 114139.

Moore, A.F. 1958. Oxygen uptake rates and respiratory quotients of aerobically decomposing synthetic garbage. MSc. Thesis. Department of Civil and Sanitary Engineering, College of Graduate Studies, Michigan State University of Agricultural and Applied Sciences, USA.

Narahara, H., Koyama, Y., Yoshida, T., Atthasampunna, P., Taguchi, H. 1984. Control of water content in a solid-state culture of Aspergillus oryzae. J. Fermentation Technol., 62:453-459.

Nigam, P., Singh, D. 1994. Solid-state (substrate) fermentation systems and their applications in biotechnology. J. Basic Microb. 6:405-423.

Ogunnaike, B.A., Ray, W.H. 1994. Process Dynamics, Modelling and Control. Oxford University Press.

Pagans, E., Barrena, R., Font, X., Sánchez, A. 2006. Ammonia emissions from the composting of different organic wastes. Dependency on process temperature. Chemosphere., 62:1534-1542

Papadimitriou, E.K. Balis, C. 1996. Comparative study of parameters to evaluate and monitor the rate of a composting process. Compost Sci. Util., 4:52-61.

Papadimitriou, E.K., Balis, C. 1997. Errata - Comparative study of parameters to evaluate and monitor the rate of a composting process. Compost Sci. Util., 5:5. 
Papadimitriou, E.K., Stentiford E.I., Alexiou, I.E. 2003. Analysis of the draft animal byproducts Order (England) by focusing upon the destruction of animal, viral pathogens at anaerobic digestion and composting facilities. In: Proc. Pathogen Control in composting and anaerobic digestion: ABPO2002, current knowledge, and technology aspects, Papadimitriou E. K. and Stentiford E. I. (Eds.) pp. 49-63.

Prior, B.A., Du Preez, J.C., Rein, P.W. 1992. Environmental parameters. In: Solid Substrate Cultivation. Doelle H.W., Mitchell D.A. and Rolz C.W. (Eds.). Elsevier Applied Sciences. pp. 65-85.

Rajamäki, T., Arnold, M., Venelampi, O., Vikman, M., Räsänen, J., Itävaara, M. 2005. An Electronic Nose and Indicator Volatiles for Monitoring of the Composting Process. Water Air Soil Poll., 162:71-87.

Rathbum, B.L., Shuler, M.L. 1983. Heat and mass transfer effects in static solid substrate fermentations: design of fermentation chambers. Biotechnol. Bioeng., 25:929-938.

Richard, T.L. 1997. The kinetics of solid-state biodegradation. PhD Thesis. Faculty of Environmental Sciences, Graduate School of the Cornell University, Ithaca, USA.

Richard, T.L., Veeken, A. De Wilde, V. Hamelers, H.V.M. 2004. Air-Filled Porosity and Permeability Relationships during Solid-State Fermentation. Biotechnol. Prog., 20:1372-1381.

Romain, A.C., Godefroid, D., Kuske, M., Nicolas, J. 2005. Monitoring the exhaust air o a compost pile as a process variable with an e-nose. Sensor Actuat. B-chem., 106:2935.

Ryoo, D., Murphy, V.G., Karim, M.N., Tengerdy, R.P. 1991. Evaporative temperature and moisture control in a rocking reactor for solid substrate fermentation. Biotechnol. Tech., 5:19-24. 
Sánchez, A. 2007. Discussion on A kinetic analysis of solid waste composting at optimal condicitons. Waste Manage., 27:854-855.

Sato, K., Nagatani, M., Sato, S. 1982. A method of supplying moisture to the medium in a solid-state culture with forced aeration. J. Fermentation Technol., 60:607-610.

Scholwin, F. 2005. Composting success through process control - A fuzzy model-based control strategy for composting facilities. PhD. Dissertation. Published by Rhombos Verlag, Berlin. ISBN 3937231781. P. 285. [In German].

Schulze, K.L. 1962. Automatic temperature and air control in composting. Compost Sci., 2:31-34

Saludes, RB, Iwachi, K, Kayanuma, A, Shiga, T. 2007. Composting of dairy cattle manure using a thermophilic-mesophilic sequence. Biosyst. Eng., 98:198-205.

Sellami, F., Jarboui, R., Hachicha, S., Medhioub, K., Ammar, E. 2008. Co-composting of oil exhausted olive-cake, poultry manure and industrial residues of agro-food activity for soil amendment. Bioresource Technol., 99:1177-1188.

Sesay, A.A., Lasaridi, K.E., Stentiford, E.I. 1998. Aerated static pile composting of municipal solid waste (MSW): a comparison of positive pressure aeration with hybrid positive and negative aeration. Waste Manage. Res., 16:264-272.

Sironi, S., Capelli, L., Centola, P., Del Rosso, R., II Grande, M. 2007. Continuous monitoring of odours from a composting plant using electronic noses. Waste Manage., 27:389-397.

Sole-Mauri, F., Illa, J., Magrí, J., Prenafeta-Boldú, F. X., Flotats, X. 2007. An integrated biochemical and physical model for the composting process. Bioresource Technol., 98:3278-3293.

Stentiford, E.I., Zane, B. 1995. Moisture and composting. In: proceedings of ORCA Congress on 'The Challenge: fitting composting and anaerobic digestion into integrated waste management'. Brussels, Belgium June 18-19. pp. 2-23. 
Steyer, J.P., Estaben, M., Polit, M. 1997. Fuzzy Control of anaerobic digestion process for the treatment of an industrial wastewater. In: Proceedings of the $19976^{\text {th }}$ IEEE International Conference on Fuzzy Systems, Part 3, pp. 1254-1249.

Szanto, G.L., Hamelers, H.V.M., Rulkens, W., Veeken, A. 2007. $\mathrm{NH}_{3}, \mathrm{~N}_{2} \mathrm{O}$ and $\mathrm{CH}_{4}$ emissions during passively aerated composting of straw-rich pig manure. Bioresource Technol., 98:2659-2670.

Tremier, A., de Guardia, A., Massiani, C., Paul, E., Martel, J.L. 2005. A respirometric method for characterising the organic composition and biodegradation kinetics and the temperature influence on the biodegradation kinetics, for a mixture of sludge and bulking agent to be co-composted. Bioresource Technol., 96:169-180.

US Composting Council. 1994. Compost Facility Operating Guide: a reference guide for composting facility and process management. The Composting Council, Alexandria, Virginia, USA.

Valencia, C. 2002. Control of Fed-batch fermentation processes by using artificial neutral systems. PhD Thesis. Departament d'Enginyeria Química. Universitat Rovira Virgili. Spain.

VanderGheynst, J.S., VanderGheynst, G.B., Walker, L.P. 1997. Measurement and analysis of biological activity in composting processes using zirconia oxide oxygen sensors. In: 1997 ASAE Annual International Meeting, Minneapolis, Minnesota, USA. ASAE Paper No. 947113.

Weppen, P. 2001. Process calorimetry on composting of municipal organic wastes. Biomass Bioenerg., 21:289-299.

Wéry, N., Lhoutellier, C., Ducray, F., Delgenès, JP., Godon, J.J. 2008. Behaviour of pathogenic and indicator bacteria during urban wastewater treatment and sludge composting, as revealed by quantitative PCR. Wat. Res., 42:53-62. 
Wichuk, K.M., McCartney, D. 2007. A review of the effectiveness of current timetemperature regulations on pathogen inactivation during composting. J. Environ. Eng. Sci., 6:573-586.

Wichuk, K.M., McCartney, D. 2008. Development of time-temperature probes for tracking pathogen inactivation during composting. Compost Sci. Util., 16:99-113.

Yager, R.P., Filev, D.P. 1994. Essentials of Fuzzy Modelling and Control. John Wiley \& Sons, Inc. 


\section{Tables}

TABLE 1

Potential controlled parameters suitable for a composting control system.

\begin{tabular}{|c|c|c|}
\hline \multicolumn{3}{|l|}{ Controlled parameter } \\
\hline $\begin{array}{l}\text { Actual controlled } \\
\text { parameter }\end{array}$ & Index parameter* & $\begin{array}{l}\text { Significant influencing } \\
\text { parameter }\end{array}$ \\
\hline Degree of aerobiosis & $\begin{array}{ll}\text { - } & \text { Macropore } \mathrm{O}_{2} \\
& \text { concentration } \\
\text { - } & \text { Microbial respiratory } \\
& \text { quotient (RQ) } \\
\end{array}$ & $\begin{array}{l}\text { - } \text { Temperature level } \\
\text { - } \text { Macropore } \mathrm{O}_{2} \\
\text { concentration } \\
\text { - } \text { Porosity } \\
\end{array}$ \\
\hline Reaction rate & $\begin{array}{ll}\text { - } & \text { Respiration rate } \\
\text { (expressed as } \mathrm{O}_{2} \\
\text { consumption or } \mathrm{CO}_{2} \\
\text { production rate) } \\
\text { - } & \text { Rate of water loss } \\
\end{array}$ & $\begin{array}{l}\text { - Temperature level } \\
\text { - Water availability } \\
\text { - Degree of aerobiosis } \\
\text { (measured as macropore } \\
\mathrm{O}_{2} \text { concentration, or } \mathrm{RQ} \text { ) } \\
\end{array}$ \\
\hline Odour potential & None known & $\begin{array}{l}\text { - Temperature level } \\
\text { - } \text { Degree of aerobiosis } \\
\text { (measured as macropore } \\
\mathrm{O}_{2} \text { concentration, and/or } \\
\text { RQ) } \\
\text { - Reaction rate }\end{array}$ \\
\hline Pathogen destruction & None known & $\begin{array}{l}\text { Temperature level } \\
\text { - Reaction rate }\end{array}$ \\
\hline Degree of homogeneity & $\begin{array}{l}\text { - Pressure drop } \\
\text { - Temperature gradient } \\
\text { - Moisture gradient } \\
\text { - Gradient of macropore } \\
\mathrm{O}_{2} \text { concentration } \\
\end{array}$ & $\begin{array}{l}\text { - } \text { Compressive stress } \\
\text { - Water availability } \\
\text { - Temperature differential } \\
\text { between the interstitial gas } \\
\text { and the material } \\
\text { composted } \\
\end{array}$ \\
\hline Retention time & $\begin{array}{ll}\text { - } & \text { Temperature level } \\
\text { - } & \text { Respiration rate } \\
& \text { (expressed as } \mathrm{O}_{2} \\
& \text { consumption or } \mathrm{CO}_{2} \\
& \text { production rate) } \\
\text { - } & \text { Cumulative loss of } \\
& \text { carbon } \\
\text { - } & \mathrm{RQ} \\
\end{array}$ & $\begin{array}{l}\text { - Temperature level } \\
\text { - Water availability } \\
\text { - Degree of aerobiosis } \\
\text { (measured as macropore } \\
\mathrm{O}_{2} \text { concentration, or } \mathrm{RQ} \text { ) }\end{array}$ \\
\hline
\end{tabular}

*Index parameter: a physical, chemical or otherwise measurable attribute of the composting ecosystem which may serve as an indicator of an actual, controlled parameter.

** Influencing parameter: a physical, chemical or otherwise measurable attribute of the compostingecosystem which may affect the value of an actual, controlled parameter. 
TABLE 2

Potential manipulated parameters and their correspondent controlled parameters of a composting control system

\begin{tabular}{|c|c|c|}
\hline Manipulated parameter & $\begin{array}{c}\text { Representative } \\
\text { measurement } \\
\text { units of a } \\
\text { manipulated } \\
\text { parameter }\end{array}$ & $\begin{array}{l}\text { Controlled parameter expected to } \\
\text { be directly affected }\end{array}$ \\
\hline Flow rate of inlet gas & $\begin{array}{l}\text { Litre/min, or } \\
\text { kg dry mass/h }\end{array}$ & $\begin{array}{ll}\text { - } & \text { Temperature level } \\
\text { - } & \text { Water availability } \\
\text { - } & \mathrm{RQ} \\
\text { - } & \text { Respiration rate } \\
\text { - } & \text { Temperature gradient } \\
\text { - } & \text { Moisture gradient }\end{array}$ \\
\hline Velocity of inlet gas & $\mathrm{m} / \mathrm{sec}$ & $\begin{array}{l}\text { Degree of aerobiosis (indicated as } \\
\mathrm{RQ} \text { ) } \\
\text { Compressive stress }\end{array}$ \\
\hline Temperature of inlet gas & & $\begin{array}{l}\text { - Temperature level } \\
\text { - Water availability } \\
\text { - Temperature gradient }\end{array}$ \\
\hline $\begin{array}{l}\text { Ratio of fresh air flow rate to } \\
\text { recirculated off-gas flow rate }\end{array}$ & Dimensionless & $\begin{array}{ll}\text { - } & \text { Water availability } \\
\text { - } & \text { Macropore } \mathrm{O}_{2} \text { concentration } \\
\text { - } & \mathrm{RQ}\end{array}$ \\
\hline $\begin{array}{l}\text { Actuation pattern of ventilation, i.e.: } \\
\text { - continuous ventilation, or } \\
\text { - intermittent ventilation }\end{array}$ & not applicable & $\begin{array}{l}\text { - } \text { Temperature gradient } \\
\text { - } \text { Moisture gradient } \\
\text { - } \text { concentration } \\
\text { Mode of movement of interstitial } \\
\text { gas }\end{array}$ \\
\hline $\begin{array}{l}\text { Pressure pattern of ventilation, i.e.: } \\
\text { - forced positive pressure; } \\
\text { - forced negative pressure; } \\
\text { - alternate positive-negative pressure; } \\
\text { and } \\
\text { - hybrid pattern as a result of off-gas } \\
\text { recirculation }\end{array}$ & not applicable & $\begin{array}{l}\text { - } \text { Temperature gradient } \\
\text { - } \quad \text { Goisture gradient } \\
\text { concentration }\end{array}$ \\
\hline $\begin{array}{l}\text { Duration of a ventilation event } \\
\text { (in case intermittent ventilation is } \\
\text { used) }\end{array}$ & minutes & $\begin{array}{ll}\text { - } & \text { Temperature level } \\
\text { - } & \text { Water availability } \\
\text { - } & \text { Regree of aerobiration rate } \\
\text { - } & \text { Temperature gradient } \\
\text { - } & \text { Goisture gradient of macropore } \mathrm{O}_{2} \\
& \text { concentration }\end{array}$ \\
\hline
\end{tabular}




\begin{tabular}{|c|c|c|}
\hline $\begin{array}{l}\text { Frequency of material mixing; and } \\
\text { Rate of reactor agitation }\end{array}$ & $\begin{array}{l}\text { events/ hour, } \\
\text { and } \\
\text { rounds/ minute, } \\
\text { or } \\
\text { strokes/minute }\end{array}$ & $\begin{array}{ll}\text { - } & \text { Temperature level } \\
\text { - } & \text { } \text { Mater availability } \\
\text { - } & \text { Respiration rate } \\
\text { - } & \text { Temperature gradient } \\
\text { - } & \text { Moisture gradient } \\
\text { - } & \text { Gradient of macropore } \mathrm{O}_{2} \\
& \text { concentration } \\
\text { - } & \text { Compressive stress } \\
\end{array}$ \\
\hline Frequency of water addition & event/day & $\begin{array}{ll} & \text { Temperature level } \\
\text { - } & \text { Water availability } \\
\text { - } & \text { Respiration rate } \\
\text { - } & \text { Moisture gradient }\end{array}$ \\
\hline Rate of water addition & $\mathrm{kg}$ water/minute & $\begin{array}{ll} & \text { Temperature level } \\
\text { - } & \text { Respirater availability } \\
\text { - } & \text { Moisture gradient } \\
& \text { Gradient of macropore } \mathrm{O}_{2} \\
& \text { concentration }\end{array}$ \\
\hline
\end{tabular}


TABLE 3

Potential disturbances of a composting process

\section{Disturbance}

Measurable on-line (Yes/No)

\begin{tabular}{ll}
\hline Thermal diffusivity of material composted & No \\
\hline Thermal conductivity of material composted & No \\
\hline Specific heat capacity of material composted & No \\
\hline Adsorption-desorption characteristics of material & \\
composted & Yes \\
\hline Interstitial gas velocity & No \\
\hline Macropore size and continuity & No \\
\hline Particle size and shape & No \\
\hline Rate of gas diffusion into and from the biofilm & No \\
\hline Rate of metabolic product diffusion into microbial cell &
\end{tabular}




\section{Figures}

Figure 1. Input and output variables of a composting process and controller

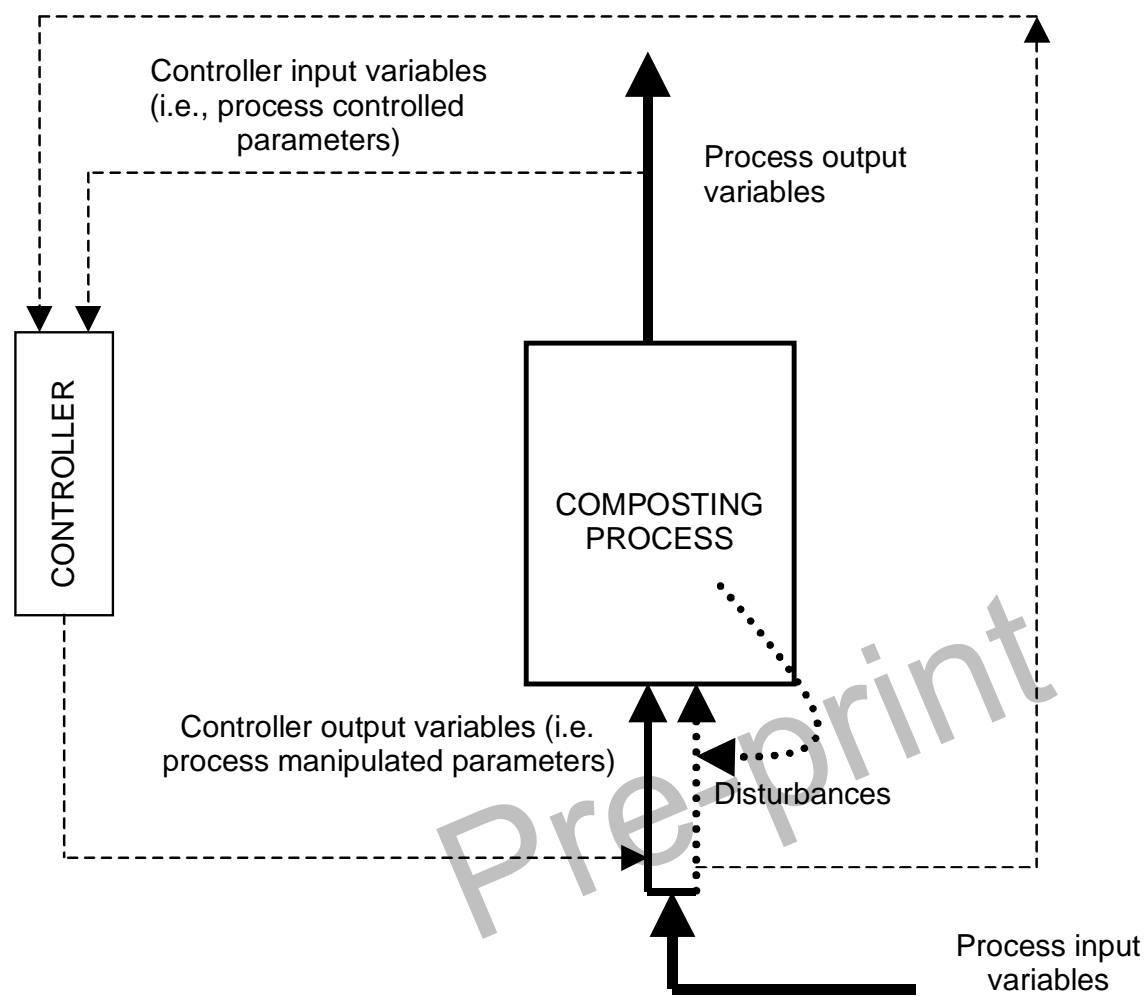

